\title{
Induced Allelopathic Effects of Thalassiosira weissflogii on Colony Formation in Phaeocystis globosa
}

\author{
Xiaodong Wang, Yiping Huo (D), Fan Yang and Yan Wang * \\ Research Center for Harmful Algae and Marine Biology, Jinan University, Guangzhou 510632, China; \\ pouchetii@gmail.com (X.W.); epingfok@163.com (Y.H.); yangfan.jnu@gmail.com (F.Y.) \\ * Correspondence: phaeocystis@foxmail.com; Tel.: +86-022-8522-1602
}

Citation: Wang, X.; Huo, Y.; Yang, F.; Wang, Y. Induced Allelopathic Effects of Thalassiosira weissflogii on Colony Formation in Phaeocystis globosa. Water 2021, 13, 581. https://doi.org/ $10.3390 /$ w13050581

Academic Editor: Haifeng Gu

Received: 4 February 2021

Accepted: 18 February 2021

Published: 24 February 2021

Publisher's Note: MDPI stays neutral with regard to jurisdictional claims in published maps and institutional affiliations.

Copyright: (c) 2021 by the authors. Licensee MDPI, Basel, Switzerland. This article is an open access article distributed under the terms and conditions of the Creative Commons Attribution (CC BY) license (https:// creativecommons.org/licenses/by/ $4.0 /)$.

\begin{abstract}
Co-culturing and using cell-free filtrates are common methods for investigating allelopathy of marine phytoplankton; however, these methods often yield inconsistent or even contradictory results. The induced release of allelopathic compounds has been hypothesized as a mechanism to explain the discrepancy. Here, we used experiments to assess the inducibility of allelopathy by the diatom, Thalassiosira weissflogii, on the colony formation of Phaeocystis globosa. T. weissflogii and its cellfree filtrates showed inhibitory effects on the growth of solitary P. globosa cells. The colony number, colony diameter, and cells per colony decreased by co-occurring T. weissflogii cells but were enhanced by their extracellular filtrates alone. Living T. weissflogii cells possibly affect the colony integrity by reducing colonial cell density of $P$. globosa. When $P$. globosa and T. weissflogii were co-cultured but separated with a $2-\mu \mathrm{m}$ membrane filter, thus allowing the exchange of extracellular secretions without direct cell contact, $P$. globosa colony concentration, colony diameter, cells per colony and colonial cell density were inhibited. Once T. weissflogii cells were pre-exposed to cell-free filtrates of P. globosa, their filtrates inhibited colony formation. T. weissflogii had allelopathic effects on P. globosa by releasing extracellular compounds that inhibited growth of solitary cells and colony formation, as well as disrupting colony integrity. However, the allelopathic effects of T. weissflogii on colony formation were only induced when the presence of $P$. globosa was perceived. Chemically mediated allelopathic effects of diatoms on colony formation of $P$. globosa may play an important role in the succession of diatoms and Phaeocystis.
\end{abstract}

Keywords: allelopathy; Phaeocystis globosa; Thalassiosira weissflogii; induced release; harmful algal blooms

\section{Introduction}

Phytoplankton are responsible for approximately half of the world's primary productivity [1], and they play key roles in global biogeochemical cycles [2]. The abundance, community structure, functions, and ecological niche separation of phytoplankton in marine ecosystems depend strongly on resource acquisition efficiency [3-5]. The ability to utilize limiting resources gives a species a competitive advantage over other members of the phytoplankton community [6,7]. However, allelopathy can alter the competitive outcomes among phytoplankton [8-10]. Some phytoplankton, particularly harmful bloom-forming species, can release a range of secondary metabolites that directly and negatively affect the growth and physiological processes of competing species [11-15]. Allelopathy, together with resource exploitation, may explain the species dominance, succession, diversity, and maintenance of harmful algal blooms [8,16,17].

Co-culturing and cell-free filtrate approaches are widely used to study allelopathic effects of phytoplankton [12-14,18,19]. The co-culturing method attempts to simulate insitu conditions where phytoplankton species co-occur and compete for limiting resources. Using filtrates, by contrast, can discriminate chemically mediated effects from exploitative competition [8]. However, it has been reported that filtrates often show weak or no 
allelopathic effects relative to living cells $[12,13,19,20]$. In some cases, filtrates of allelopathic species even stimulate the growth of the target species [12,19,21-23], and direct cell contact between donor and target species has been considered as a prerequisite for allelopathic effects $[13,20,23]$.

Phytoplankton can adjust their biochemical processes and metabolism profiles in response to the presence of competitors and associated extracellular metabolites. Corcoran et al. [24] provide direct experimental evidence showing the induced allelopathic interactions of freshwater microalgae. The growth of Chlorella was not influenced by cell-free exudates of Coelastrella but was inhibited by exudate obtained from co-culture of Chlorella and Coelastrella [24]. Similar induced responses have been documented in marine algae. Several substances that were present exclusively in monocultures of either Thalassiosira weissflogii or Skeletonema costatum were not detectable in the co-culture [25]. Following these observations, one may postulate that certain allelopathic effects also involve induced release of allelopathic compounds $[12,19]$. The allelopathic compounds are generated and released only when the target species or their extracellular metabolites are perceived, but absent in the filtrates released by the donor species grown alone. The induced release of allelopathic compounds may explain the discrepancy in effects between filtrates and living cells.

Phaeocystis is a cosmopolitan marine phytoplankton genus that plays a significant role in carbon and sulfur cycles, marine food webs and potential climate change [26-28]. It has a unique polymorphic life cycle, alternating between gelatinous colonies up to serval centimeters in diameter and solitary cells of only a few micrometers in size $[29,30]$. Blooms of colonial P. globosa typically follow diatom blooms in coastal waters [27,31-34]. For example, Thalassiosira bloomed in January 2017, while P. globosa colonies bloomed in February in the coastal waters of the South China Sea [35]. In previous work, we observed that colony formation of P. globosa was inhibited by living Thalassiosira cells but was stimulated by their filtrates (Wang et al., under review). Here, we conducted experiments to assess whether the allelopathy of $T$. weissflogii is induced by the presence of $P$. globosa. As diatoms and Phaeocystis are critical components of coastal phytoplankton communities, this study increases our knowledge about the underlying mechanisms governing phytoplankton succession and the occurrence of blooms.

\section{Materials and Methods}

Phytoplankton

Non-axenic P. globosa and T. weissflogii were isolated from the Beibu Gulf $\left(21^{\circ} 10.12 \mathrm{~N}\right.$, $108^{\circ} 37.12 \mathrm{E}$ ) in February 2019. All phytoplankton were cultured in $\mathrm{f} / 2$ medium [36] with a salinity of 30 at $20^{\circ} \mathrm{C}$ under $100 \mu \mathrm{mol}$ photons $\mathrm{m}^{-2} \mathrm{~s}^{-2}$ in a light:dark cycle of $14: 10 \mathrm{~h}$. The cultures were maintained in exponential growth by dilutions with fresh medium every 5-7 days. Prior to the experiments, solitary cells of P. globosa were collected by filtering the stock through a $20 \mu \mathrm{m}$ sieve twice under gravity [37,38].

Experiment 1: Co-occurrence of P. globosa and T. weissflogii

To study the effects of co-occurring diatoms on the growth and colony formation of P. globosa, solitary P. globosa cells and T. weissflogii were transferred into three $150 \mathrm{~mL}$ flasks. Each flask was considered a treatment. Another three flasks containing only solitary P. globosa cells were used as controls. Cell abundances of $P$. globosa and diatoms were respectively adjusted to 10,000 and 107 cells $\mathrm{mL}^{-1}$ with $\mathrm{f} / 2$ medium, yielding approximately equal carbon concentrations of $0.13 \mu \mathrm{g} \mathrm{mL}^{-1}$ at the start of each experiment. The cellular volumes of $P$. globosa and diatoms were calculated from cellular dimensions using the appropriate geometric models [39] and then converted to carbon biomass using equations from [40]. The starting carbon concentrations used in the present experiment were within the range of those in the coastal waters where the P. globosa bloom occurred [32]. All flasks were placed in a shaking incubator (New Brunswick, Eppendorf, USA) at $25 \mathrm{rpm}$ at $20^{\circ} \mathrm{C}$ with $100 \mu \mathrm{mol}$ photons $\mathrm{m}^{-2} \mathrm{~s}^{-1}$ under a light:dark cycle of $12: 12 \mathrm{~h}$. Incubations lasted for 10 days. An aliquot of $50 \mathrm{~mL}$ was removed daily from each flask; the removed 
volume was replaced by $\mathrm{f} / 2$ medium. Solitary cell abundances and colony numbers in the drawn aliquots were measured every two days. Colony diameter and cells per colony were measured on day 10 . The $\mathrm{pH}$ values were measured every other day using a Sentron $\mathrm{pH}$ meter (ArgusX, Cole-Parmer, USA) that was pre-calibrated using buffers of $\mathrm{pH} 7.0$ and 10.0. Dissolved nutrient analysis was also determined on day 10; a $100 \mathrm{~mL}$ subsample was filtered through a $0.22 \mu \mathrm{m}$ membrane filter (Millipore, USA) and stored frozen at $-20{ }^{\circ} \mathrm{C}$ until analysis. Dissolved inorganic nitrate, ammonium, nitrite and phosphorus were measured using standard colorimetric methods [41].

Experiment 2: Exposure to T. weissflogii exudates

An experiment was carried out to assess whether inhibitory effects on growth and colony formation was mediated by $T$. weissflogii exudates. T. weissflogii were inoculated in a 1-liter beaker containing f/2 medium. Each day, $200 \mathrm{~mL}$ of the diatom cultures were replaced by $200 \mathrm{~mL} \mathrm{f/2}$ medium. Exudates were obtained daily by filtering cultures through $0.22 \mu \mathrm{m}$ polycarbonate membrane filters (Sigma-Aldrich, USA) at a vacuum of $<100 \mathrm{~mm} \mathrm{Hg}$. The removed volume was replaced with $\mathrm{f} / 2$ medium to maintain the exponential growth of diatoms. Cell-free filtrates were enriched with $\mathrm{f} / 2$ nutrients to create "enriched filtrates" for the experiments.

The experiment was conducted in six $250 \mathrm{~mL}$ polystyrene flasks containing solitary P. globosa cells with a starting cell abundance of $10^{4}$ cells $\mathrm{mL}^{-1}$. All flasks were placed in a shaking incubator and maintained under the same conditions as in Experiment 1. Aliquots of $50 \mathrm{~mL}$ culture were removed from each flask daily. Ten milliliters of enriched cell-free filtrates and $40 \mathrm{~mL} \mathrm{f} / 2$ medium were added to three flasks that were designated as treatments, and the remaining three flasks received $50 \mathrm{~mL} f / 2$ medium and were designated as controls. All incubations lasted for 10 days. The removed aliquots were used to measure solitary cell abundances, colony numbers and $\mathrm{pH}$ every other day. Colony diameters and cells per colony in P. globosa were measured on day 10.

Experiment 3: Effects of continuous exposure to exudates

To investigate whether release of allelopathic chemicals is induced, T. weissflogii and P. globosa were continuously exposed to each other's extracellular exudates. T. weissflogii were transferred to three $50 \mathrm{~mL}$ centrifuge tubes (BD Biosciences, USA) for the treatment; P. globosa was added to another three tubes as controls. All tubes were covered with a $2 \mu \mathrm{m}$ polycarbonate filter (Millipore, MA, USA) at the mouth [42], and each was placed into a 1-liter beaker containing $500 \mathrm{~mL}$ solitary $P$. globosa with a starting concentration of $10^{4}$ cells $\mathrm{mL}^{-1}$. The polycarbonate filter allowed the exchange of dissolved chemicals between the tube and the beaker without direct cell contact between the two compartments [42]. The incubations lasted for 10 days under the same conditions as in Experiments 1 and 2. To facilitate the exchange of dissolved chemicals, the tubes were gently inverted ten times daily. Every day, a $100 \mathrm{~mL}$ aliquot was removed from each beaker and replaced by $100 \mathrm{~mL}$ f/ 2 medium. P. globosa solitary cell concentration, colony numbers, colony diameters, cells per colony, and $\mathrm{pH}$ were determined as described above.

Experiment 4: Pre-exposure experiment

Here, we further tested the inducibility of the release of allelopathic compounds. First, we pre-exposed T. weissflogii to the cell-free filtrate of P. globosa. Then, we inoculated P. globosa cells with exudates extracted from those pre-exposed diatoms. T. weissflogii were inoculated individually in 1-liter beakers containing f/2 medium. Each day, $200 \mathrm{~mL}$ of the diatom cultures were replaced by $100 \mathrm{~mL}$ of cell-free filtrate of $P$. globosa plus $100 \mathrm{~mL}$ of $\mathrm{f} / 2$ medium. Diatom cultures were then filtered through $0.22 \mu \mathrm{m}$ filters at a vacuum of $<100 \mathrm{~mm} \mathrm{Hg}$ and enriched with $\mathrm{f} / 2$ nutrient to obtain exudates from the pre-exposed diatoms that were then used for the experiment.

The experiment consisted of six $250 \mathrm{~mL}$ flasks with P. globosa at a starting cell concentration of $10^{4}$ cells $\mathrm{mL}^{-1}$. The filtrates of pre-exposed diatoms were added to three of the flasks that were considered as treatments, while the remaining three flasks without the addition of diatom filtrates were used as the controls. A $50 \mathrm{~mL}$ aliquot from each flask was 
replaced daily by either $50 \mathrm{~mL} \mathrm{f} / 2$ medium (control flasks) or $10 \mathrm{~mL}$ diatom filtrates plus $40 \mathrm{~mL} \mathrm{f} / 2$ medium (treatment flasks). The incubations lasted for 10 days. The removed aliquots were used to measure solitary cell abundances, colony numbers, and $\mathrm{pH}$ every other day. Colony diameters and cells per colony were determined on day 10 .

Microscopic analysis

Samples for microscopic measurements of solitary cell abundance, colony number, colony diameter and cells per colony of $P$. globosa were collected with a wide-mouth pipette and fixed with acid Lugol's solution [37]. Solitary cell abundances were determined with $1 \mathrm{~mL}$ Sedgewick Rafter chambers using a Nikon inverted microscope; randomly selected fields of view were chosen until 200 cells were counted per replicate. P. globosa colonies were allowed to settle in 24-well plates for two hours; thirty colonies were randomly chosen in each sample to measure colony diameters and numbers of cells per colony. If number of colonies was smaller than 30 colonies $\mathrm{mL}^{-1}$, all colonies were measured. All samples were processed within one day of collection to prevent colony disintegration [37,38].

Statistical analysis

Statistical analyses and graphic presentations were performed using GraphPad Prism version 7.0.0 for Windows (GraphPad Software, San Diego, California USA). All data were checked for normality by the D'Agostino-Pearson normality test. Statistical differences in solitary cell abundances, colony numbers, and $\mathrm{pH}$ between treatments and controls were assessed using two-way ANOVA with the Geisser-Greenhouse correction followed by Sidak's multiple comparisons test. Nonparametric Mann-Whitney tests were used to compare the differences in colony diameters and cells per colony between treatments and controls. Pearson's correlation coefficients were calculated to assess relationships between observed cells per colony and the colony diameter. A comparison of regression lines was done by analysis of covariance (ANCOVA). The significance level was set a priori at a critical $p$-value of 0.05 .

\section{Results}

\subsection{Co-occurrence with T. weissflogii}

Solitary cell abundances in the treatment and control increased rapidly until maximum values were reached at day 10 (Figure 1a). Solitary cell abundances were significantly lower when P. globosa was cultured with T. weissflogii relative to when grown alone $(p<0.01$; Figure 1a). Numbers of colonies in the treatment were fewer than 91 colonies $\mathrm{mL}^{-1}$ and significantly lower compared to the control $(p<0.01$; Figure $1 b)$. The $\mathrm{pH}$ values in coculture of P. globosa and T. weissflogii and monoculture of P. globosa were 8.57 and 8.46, respectively, on day 10 (Figure 1c). At the end of the experiment, nitrate concentrations were $>753 \mu \mathrm{M}$, while phosphate and silicate concentrations were above 25.3 and $79.4 \mu \mathrm{M}$, respectively, suggesting that there was no nutrient limitation for phytoplankton growth (Table 1).

Table 1. Inorganic nutrient concentrations (mean \pm S.D., $n=3$ ) on day 10 of Experiment 1.

\begin{tabular}{cccccc}
\hline & \multicolumn{5}{c}{ Inorganic Nutrient $(\mu \mathrm{mol} \mathrm{L}-\mathbf{1})$} \\
\cline { 2 - 6 } & Nitrate & Phosphate & Ammonium & Nitrite & Silicate \\
\hline Control & $771.6 \pm 48.7$ & $25.3 \pm 0.6$ & $2.4 \pm 0.3$ & $0.2 \pm 0$ & $105.7 \pm 9.7$ \\
Treatment & $753.7 \pm 35.2$ & $26.3 \pm 2.6$ & $1.8 \pm 0.5$ & $0.1 \pm 0$ & $79.4 \pm 4.9$ \\
\hline
\end{tabular}



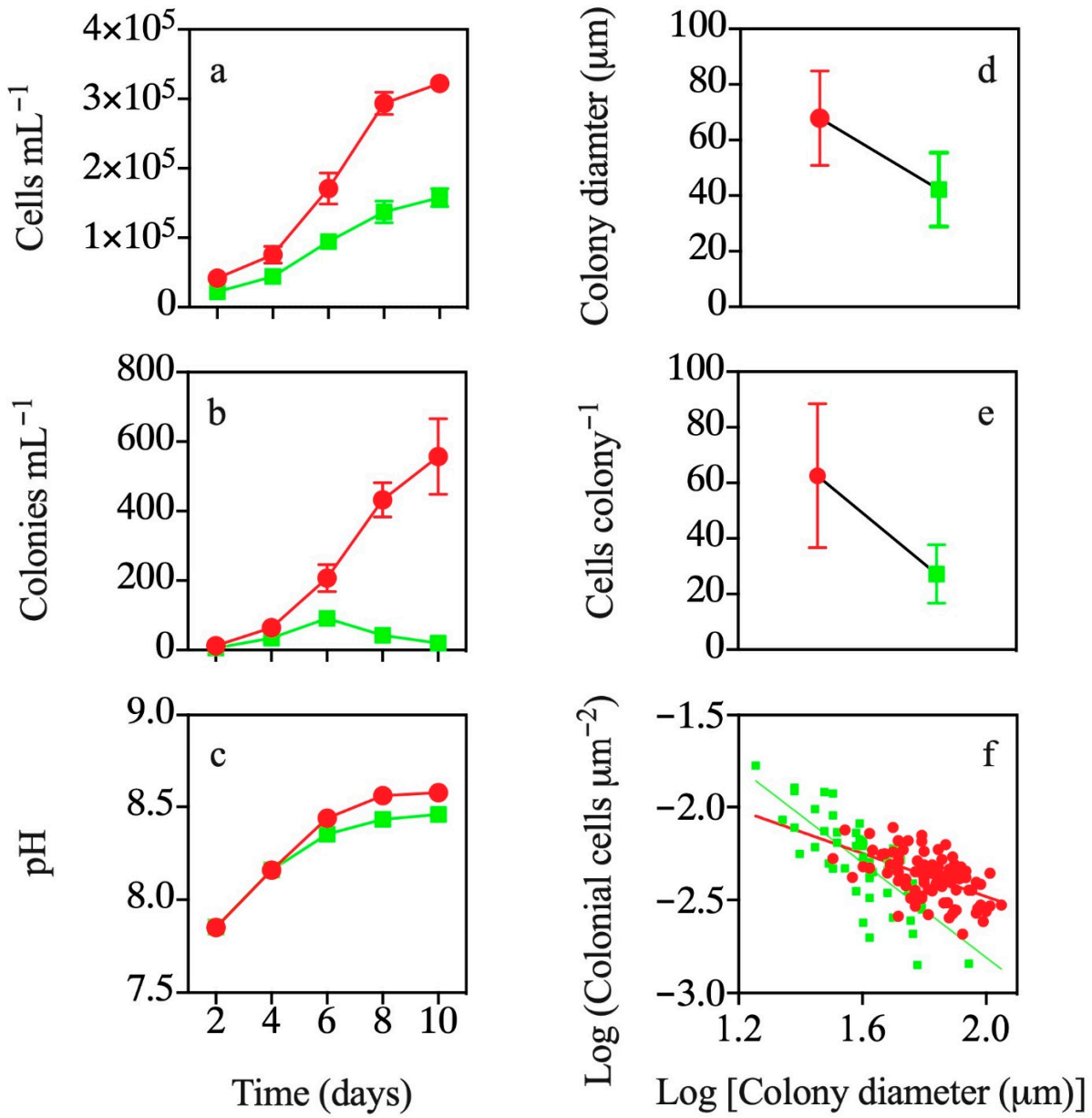

Figure 1. (a) The solitary cell abundances (Mean $\pm \mathrm{SD}, n=3$ ), (b) the number of colonies (Mean $\pm \mathrm{SD}$, $n=3$ ), (c) $\mathrm{pH}$ (Mean $\pm \mathrm{SD}, n=3$ ), (d) colony diameters (Mean $\pm \mathrm{SD}, n=90$ and 58 for control and treatment, respectively), (e) the number of cells per colony (Mean $\pm \mathrm{SD}, n=90$ and 58 for control and treatment, respectively) and (f) linear relationship between Log (colonial cells $\mu \mathrm{m}^{-2}$ ) and Log [colony diameter $(\mu \mathrm{m})$ ] $(n=90$ and 58 for control and treatment, respectively) in $P$. globosa grown alone (red circles) and co-cultured with T. weissflogii (green squares).

The average colony diameter in the control was $67.9 \mu \mathrm{m}, 38 \%$ larger than that of the treatment $(p<0.01$; Figure 1d). Cells per colony decreased by $57 \%$ on day 10 of the experiment when co-cultured with T. weissflogii ( $p<0.01$; Figure 1e). There was a negative linear relationship between Log (colonial cells $\mu \mathrm{m}^{-2}$ ) and $\log$ [colony diameter $(\mu \mathrm{m})$ ] for colonies in the treatment and control ( $p<0.01$; Figure 1f). The absolute value of slope of the regression for colonies in the treatment was significantly higher than that of the control $(p<0.01$; Figure 1f).

\subsection{Effects of Exposure to T. weissflogii Exudates}

P. globosa solitary cell abundance in both treatment and control increased over the first eight days (Figure 2a); however, solitary cell abundances decreased significantly by cell-free filtrates of T. weissflogii relative to the control $(p<0.05$; Figure $2 \mathrm{a})$. The number of colonies in treatment and control increased throughout the experiment and reached their maximum values at day 10 (Figure $2 b$ ). However, colony numbers in P. globosa were significantly higher when exposed to filtrates of T. weissflogii compared to the control $(p<0.01$; Figure 2b). The $\mathrm{pH}$ values in co-culture of P. globosa and T. weissflogii were significantly lower than those in the monoculture of $P$. globosa throughout the experiment $(p<0.01$; Figure 2c). 

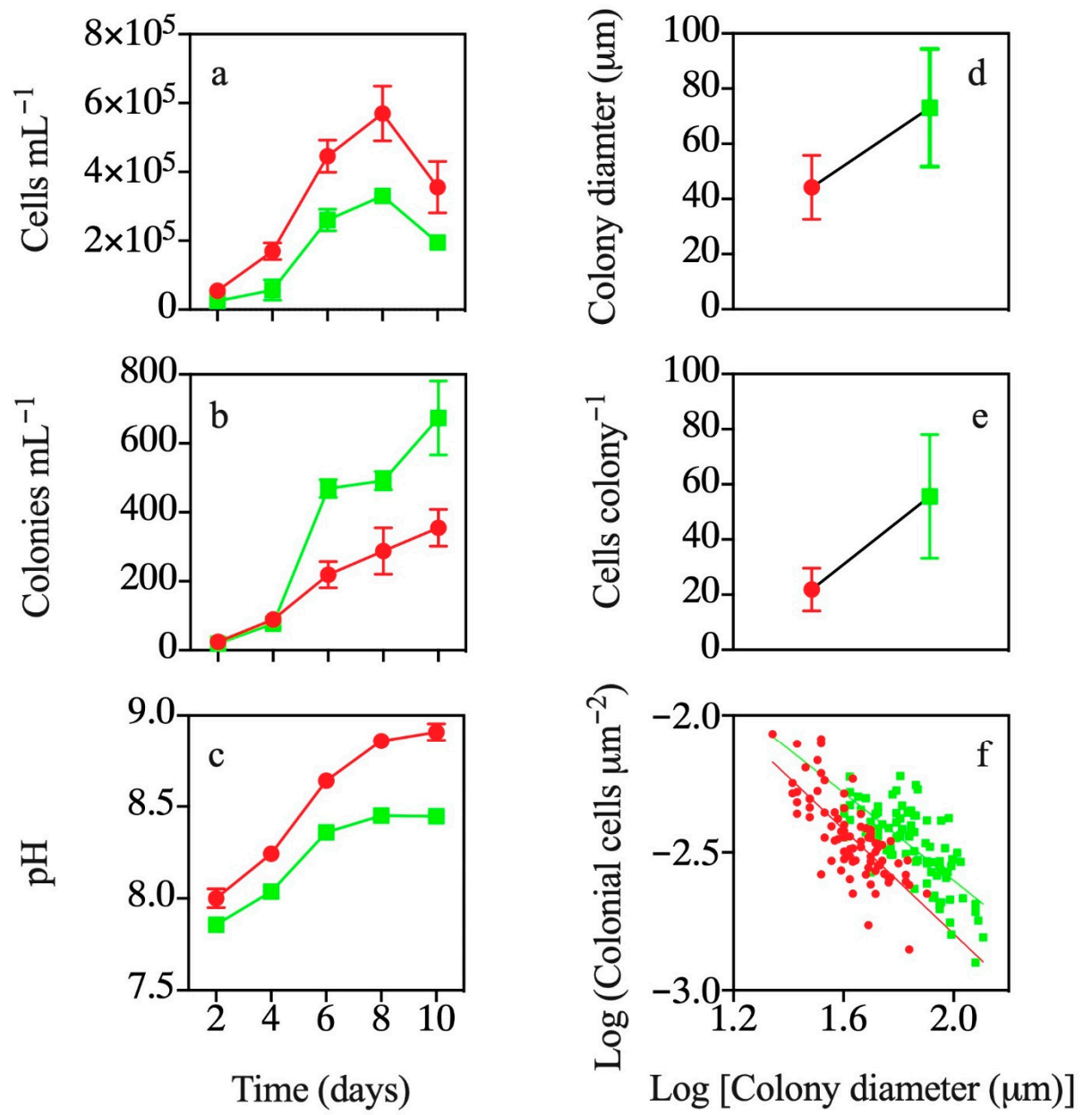

Figure 2. (a) The solitary cell abundances (Mean $\pm \mathrm{SD}, n=3$ ), (b) the number of colonies (Mean $\pm \mathrm{SD}$, $n=3$ ), (c) $\mathrm{pH}$ (Mean $\pm \mathrm{SD}, n=3$ ), (d) colony diameters (Mean $\pm \mathrm{SD}, n=90$ ), (e) the number of cells per colony (Mean $\pm \mathrm{SD}, n=90$ ) and (f) linear relationship between Log (colonial cells $\mu^{-2}$ ) and Log [colony diameter $(\mu \mathrm{m})]$ ( $n=90$ for control and treatment) in P. globosa grown alone (red circles) and exposed to cell-free filtrates of T. weissflogii (green squares).

The average colony diameter and cells per colony of $P$. globosa exposed to filtrates of T. weissflogii were $65 \%$ and $155 \%$ higher relative to controls $(p<0.01$; Figure $2 \mathrm{~d}$,e), respectively. There were negative linear relationships between Log (colonial cells $\mu \mathrm{m}^{-2}$ ) and $\log$ [colony diameter $(\mu \mathrm{m})$ ] for colonies in the treatment and control $(p<0.01$; Figure 2f). There was not a significant difference in slopes between treatment and control $(p=0.22$; Figure 2f).

\subsection{Effects of Continuous Exposure to T. weissflogii Exudates}

Following a continuous exposure to dissolved chemicals from T. weissflogii diffused through a 2- $\mu \mathrm{m}$ membrane, both solitary cell growth and colony formation of $P$. globosa were significantly decreased ( $p<0.01$; Figure $3 a, b)$. By day 10 , solitary cell concentration and the number of colonies of $P$. globosa in the treatments were at least $72 \%$ lower than in the controls $(p<0.01$; Figure $3 \mathrm{a}, \mathrm{b})$. There was no difference in $\mathrm{pH}$ values between the co-culture of P. globosa and T. weissflogii and monoculture of P. globosa throughout the experiment $(p>0.05$; Figure $3 c)$. 

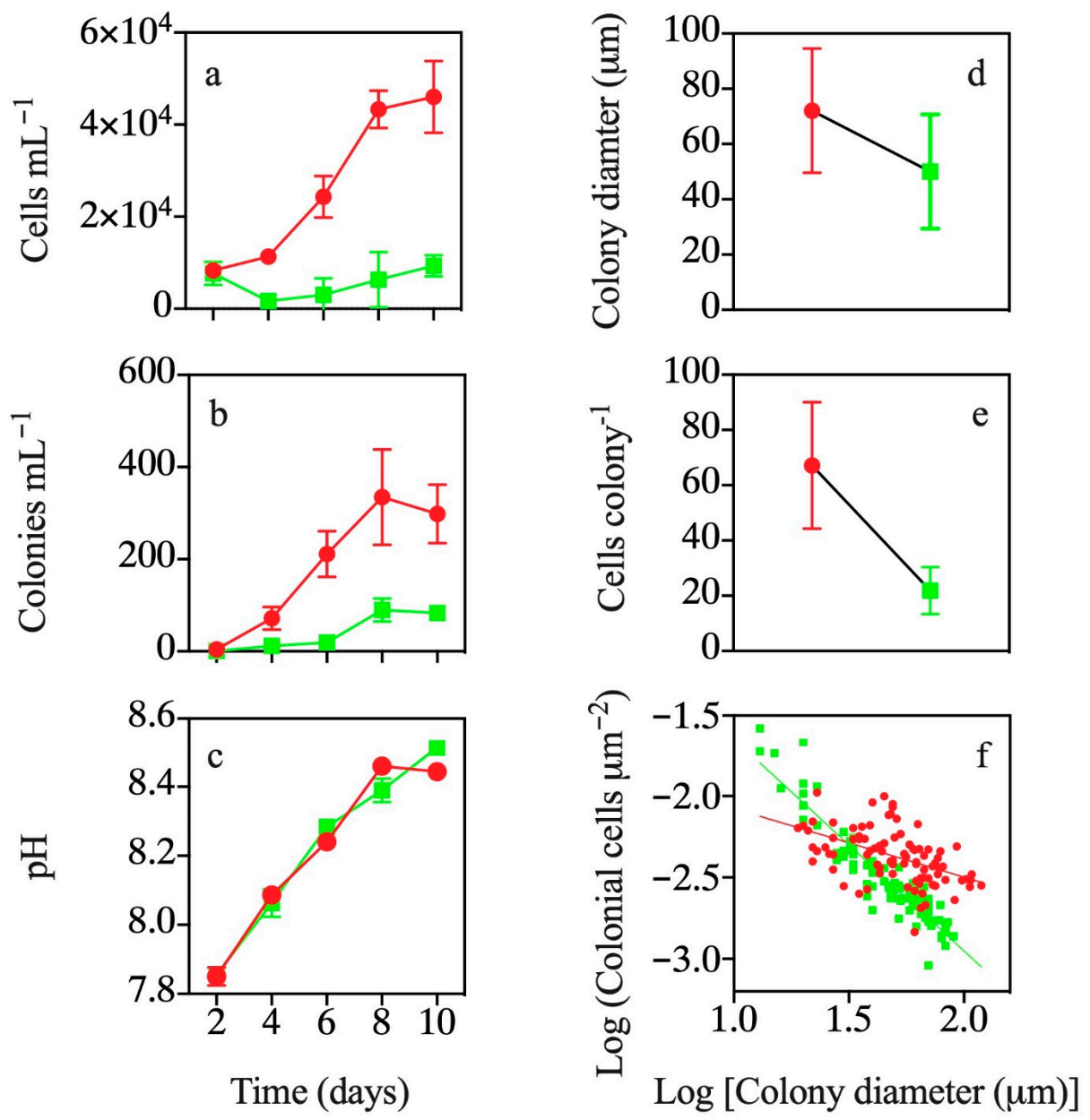

Figure 3. (a) The solitary cell abundances (Mean $\pm \mathrm{SD}, n=3$ ), (b) the number of colonies (Mean $\pm \mathrm{SD}$, $n=3$ ), (c) $\mathrm{pH}$ (Mean $\pm \mathrm{SD}, n=3$ ), (d) colony diameters (Mean $\pm \mathrm{SD}, n=90$ ), (e) the number of cells per colony (Mean $\pm \mathrm{SD}, n=90$ ) and (f) linear relationship between Log (colonial cells $\mu_{\mathrm{m}}^{-2}$ ) and Log [colony diameter $(\mu \mathrm{m})]$ ( $n=90$ for control and treatment) in P. globosa grown alone (red circles) and exposed to T. weissflogii extracellular exudates diffused through a $2-\mu \mathrm{m}$ filter (green squares).

The average colony diameters and cells per colony were $31 \%$ and $68 \%$ lower compared to the control, respectively $(p<0.01$; Figure $3 \mathrm{~d}, \mathrm{e})$. We found a negative linear relationship between Log (colonial cells $\mu \mathrm{m}^{-2}$ ) and Log [colony diameter $(\mu \mathrm{m})$ ] for colonies in the control and treatment $(p<0.01$; Figure 3f). The absolute value of the slope of the regression line in the control was lower than that of the treatment $(p<0.01$; Figure 3f).

\subsection{Effects of Exudates of Pre-Exposed T. weissflogii}

Solitary cell abundances were reduced significantly by filtrates from T. weissflogii that were pre-exposed to filtrates of P. globosa $(p<0.01$; Figure 4a). Filtrates of pre-exposed T. weissflogii decreased P. globosa colony abundances by $94 \%$ on day $10(p<0.01$; Figure $4 \mathrm{~b})$. The $\mathrm{pH}$ values in co-culture of $P$. globosa and $T$. weissflogii were significantly lower than those in the monoculture of $P$. globosa $(p<0.01$; Figure $4 c)$.

The average colony diameters and cells per colony were 29\% ( $p<0.01$; Figure $4 \mathrm{~d})$ and $68 \%(p<0.01$; Figure $4 \mathrm{e})$ reduced by filtrates of pre-exposed T. weissflogii, respectively. There was a negative linear relationship between Log (colonial cells $\mu \mathrm{m}^{-2}$ ) and Log [colony diameter $(\mu \mathrm{m})]$ for colonies in the treatment and control $(p<0.01$; Figure $4 \mathrm{f})$. The absolute value of the slope of the regression line for colonies in the control was lower than in the treatment $(p<0.01$; Figure $4 \mathrm{f})$. 

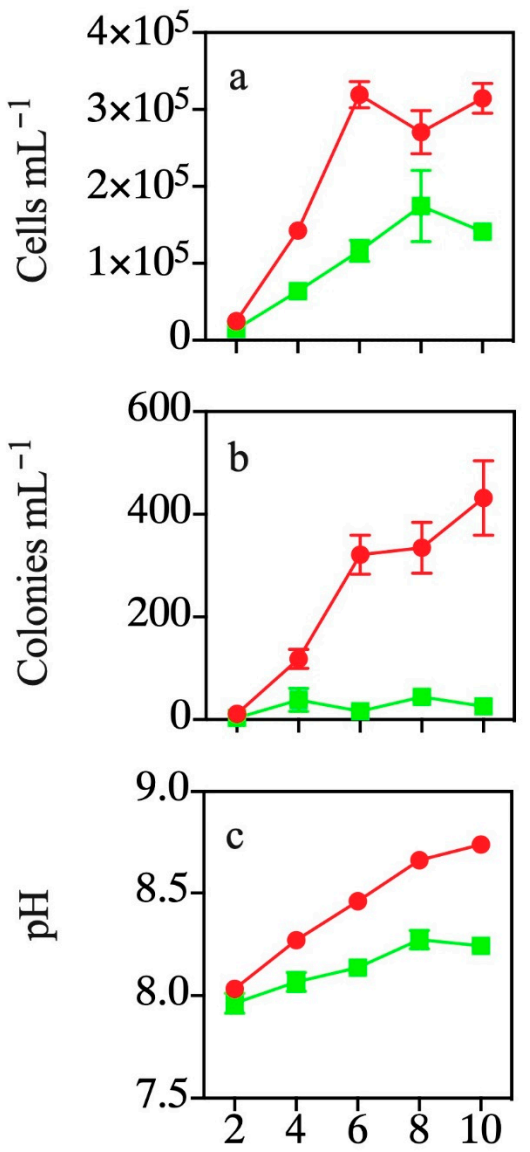

Time (days)
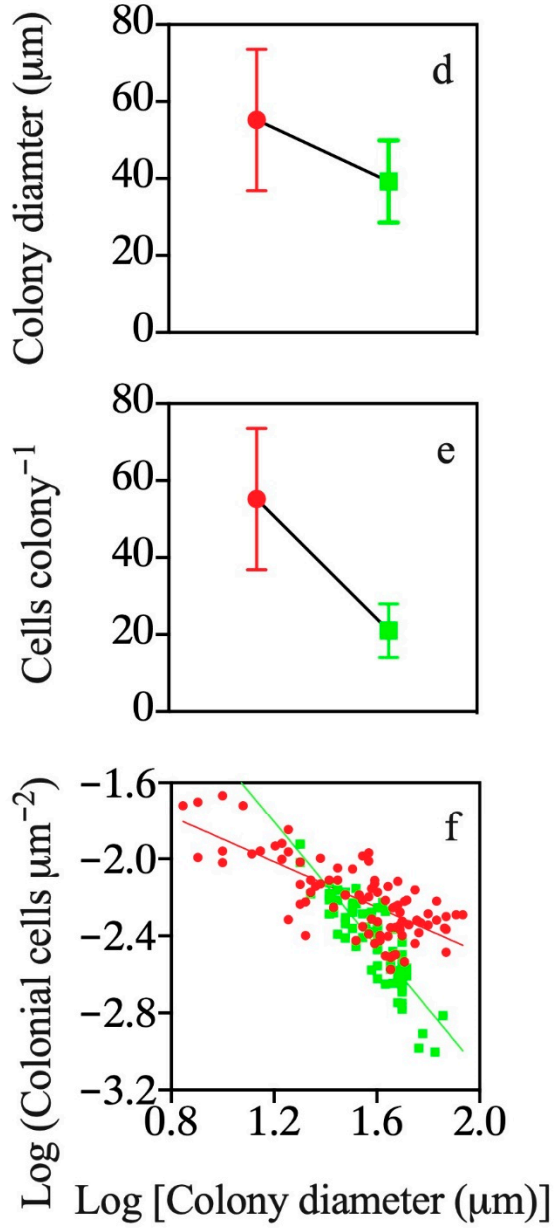

Figure 4. (a) The solitary cell abundances (Mean $\pm \mathrm{SD}, n=3$ ), (b) the number of colonies (Mean $\pm \mathrm{SD}$, $n=3$ ), (c) $\mathrm{pH}$ (Mean $\pm \mathrm{SD}, n=3$ ), (d) colony diameters (Mean $\pm \mathrm{SD}, n=90$ and 77 for control and treatment, respectively), (e) the number of cells per colony (Mean $\pm \mathrm{SD}, n=90$ and 77 for control and treatment, respectively) and (f) linear relationship between Log (colonial cells $\mu \mathrm{m}^{-2}$ ) and Log [colony diameter $(\mu \mathrm{m})$ ] $(n=90$ and 77 for control and treatment, respectively) in $P$. globosa grown alone (red circles) and exposed to extracellular exudates of T. weissflogii pre-exposed to filtrates of $P$. globosa (green squares).

\section{Discussion}

Chemicals are used widely by phytoplankton to suppress growth and even cause death of competitors in marine ecosystems [12-15,18], which has been considered an allelopathic effect $[8,9]$. In agreement with previous investigations, we found that Thalassiosira weissflogii cells and their extracellular exudates showed consistently negative effects on the growth of solitary cells of $P$. globosa. By contrast, elevated $\mathrm{pH}$ has been observed to influence the growth and succession of phytoplankton $[43,44]$. For example, Phaeocysits growth remained constant when $\mathrm{pH}$ increased from 8 to 8.8 but was negatively affected once $\mathrm{pH}$ reached 9.0 [45]. In the present experiment, elevated $\mathrm{pH}$ in the treatment was only observed when P. globosa co-occurred together with T. weissflogii (Exp. 1). However, the maximum $\mathrm{pH}$ in the treatments was 8.57, only 0.11 higher than those in the control (8.46), suggesting that elevated $\mathrm{pH}$ is unlikely to alter the growth of Phaeocystis. Given that there was neither nutrition limitation nor $\mathrm{pH}$ effects during the experiments, allelopathic chemical substances generated and released by diatoms appear to be responsible for the decreased growth of solitary cells.

T. weissflogii cells were inhibitory for the colony formation in our experiments. However, cell-free filtrates did not show any inhibitory effects on colony formation. Indeed, filtrates of $T$. weissflogii stimulated colony formation and resulted in a larger colony diame- 
ter. Kubanek et al. [12] also found that the cell abundance of diatoms and dinoflagellates were negatively affected by living Karenia brevis but enhanced by K. brevis filtrates. The discrepancy in inhibitory effects between the filtrate and living cells led to the assumption that allelopathic substances associated with dinoflagellates damaging the cell membrane of target cells depend on cell contact $[20,46]$. The direct cell contacts with allelopathic dinoflagellates cause target species to become immobile, morphologically abnormal, and suffer lysis or declined growth rates $[13,23,46]$, whereas cell-free filtrates play minor roles in the interactions between dinoflagellates [20]. However, this is not a case for the inhibitory effects of diatoms on colony formation of P. globosa. In co-occurrence experiments (Experiment 1), living T. weissflogii cells resulted in a $58 \%$ decrease in the maximum colony number. Once P. globosa and diatoms were co-cultured but separated by a $2-\mu \mathrm{m}$ membrane filter, thus allowing the exchange of extracellular metabolites without cell contact, the maximum colony number was deceased by $72 \%$. Extracellular metabolites that diffused through a filter triggered more severe inhibitory effects, showing that cell contact was not required for interactions between T. weissflogii and P. globosa.

Bacteria are likely to interfere with chemical-mediated interactions between diatoms and P. globosa by decomposing allelopathic compounds or by releasing harmful extracellular substances [12,47]. However, several studies have shown that bacteria play no role in allelopathy of phytoplankton [48-50]. Cultures of diatoms used in the present study were not axenic, and no attempt was made to remove bacteria in order to mimic the field conditions. Inhibitory effects on solitary cells and colony formation, as shown in Experiment 1,3 and 4, indicated that the degradation of allelopathic compounds by bacteria, if occurring during the experiments, was unlikely to influence the potency of allelopathic chemicals. In Experiment 2 and 4, P. globosa was exposed to cell-free filtrates of T. weissflogii. The cell-free filtrates of $T$. weissflogii and pre-exposed diatoms were unlikely to have shown opposite effects if bacteria played major roles in the interaction. In addition, intact and healthy colonies are often found to be free of bacteria [51,52], suggesting that colony formation is not affected by bacteria.

There is some evidence implying the potential induced defense in marine phytoplankton $[14,25,50,53]$. For example, it has been reported that co-occurring with diatom S. costatum weakens the allelopathic effects of exudates of dinoflagellate K. brevis $[14,50]$. When co-cultured with competitive dinoflagellates and diatoms, metabolism profiles and biochemical processes of diatoms were altered $[25,53]$. Some compounds were not produced and released [25,50], while the concentrations of certain compounds increased [53]. In the present experiments, the presence of P. globosa and/or their exudate induced alteration in extracellular metabolites of $T$. weissflogii. It is possible that $T$. weissflogii grown alone generates and releases extracellular substances that are responsible for the stimulatory effect on colony formation. When co-occurring with P. globosa, however, these stimulatory compounds were not produced and excreted. Instead, T. weissflogii released allelopathic compounds on colony formation of P. globosa. T. weissflogii can sense and identify the extracellular metabolites associated with P. globosa. When exposed to the extracellular exudates associated with $P$. globosa, regardless of whether they were released by co-occurring P. globosa, diffused through a filtrate or added daily, colony formation was also suppressed. Thus, the generation and excretion of allelopathic compounds by T. weissflogii are induced by the presence of P. globosa or associated metabolites.

The biosynthesis and release of extracellular metabolites are flexible processes for diatoms. Certain allelopathic chemicals, such as compounds that are responsible for inhibitory effects on the growth of solitary cells, were synthesized and released regardless of the presence of P. globosa. Allelopathic effects on colony formation may result from changes in metabolic profiles once diatoms detect $P$. globosa and its extracellular metabolites in the environment. Diatoms release multiple chemicals [22], some of which control growth of solitary cells, while others may be responsible for the regulation of colony formation. However, the mechanisms underlying the induced release of allelopathic chemicals are not fully understood. Biosynthesis and transport of organic allelopathic chemicals are generally 
energy-demanding $[17,54]$, and limiting photosynthesis production must be a priority allocated to growth or reproduction to optimize the energy expenditures when competitors are not present [6]. Allocation of limited resources to the release of allelopathic products prevents the use of these resources in cell division and reproduction, representing an allocation cost [8]. The induced release of allelopathic chemicals for diatoms in the presence of competitors is an act of balance to optimize fitness and should be further investigated.

The success of Phaeocystis in marine systems is generally ascribed to colony formation $[55,56]$. Large colonies create a size-mismatch problem for small grazers, thereby providing protection for colonial cells [57]. Colony formation of Phaeocystis forces grazers to feed on alternative resources such as diatoms, thereby increasing the mortality of diatoms [58]. However, competitive T. weissflogii may weaken the protection by disrupting the colony integrity. T. weissflogii results in steeper slopes of the linear relationship between colonial cell density and colony diameter, indicating that cell number per unit surface area for colonies (colonial cell density) in the treatment is lower relative to the control at a given colony diameter. The relatively lower colonial cell density could be the result of the higher extent of inhibitory effects on growth of colonial diameter relative to colony size. For example, colony diameter was decreased by $38 \%$ on day 10 , while cells per colony was reduced by $57 \%$, by co-occurring Thalassiosira sp. (Experiment 1 ). The colony envelope becomes thinner and more fragile as colonial cell density decreases because the amount of carbon required to build the colonial mucilaginous envelope exceeds the ability of colonial cells to produce the mucous $[59,60]$. Once colonies rupture, cells are released in the water column and may be consumed by zooplankton [61]. Thus, inhibitory effects on colonial cell density pose a major challenge for the survival of colonial cells.

Inhibitory effects on solitary cells and colony formation are of ecological significance for diatoms. Decreased solitary cells and colonial cells allow more nutrients to be available for diatoms. In contrast, decreased colony integrity can weaken the protection function of the colony size, stimulating grazers to consume more colonial cells and reducing the grazing pressure on diatoms. In the coastal waters of the South China Sea, Thalassiosira dominated the phytoplankton community before the colonial P. globosa bloom [35]. Allelopathic effects become significant when donor species are at cell densities of typical of blooms [17]. Allelopathic effects of Thalassiosira suppress the biomass accumulation of colonial Phaeocystis, further preventing the occurrence of Phaeocystis blooms prior to diatom blooms. Our study provides information about the environmental factors that can control algal blooms and thus improves our understanding of the ecological dynamics in marine ecosystems.

Author Contributions: Conceptualization, X.W. and Y.W.; methodology, X.W., Y.H. and F.Y.; software, X.W.; validation, X.W. and Y.W.; formal analysis, X.W.; investigation, X.W., Y.H. and F.Y.; resources, Y.W.; data curation, X.W. and Y.W.; writing - original draft preparation, X.W., Y.H., F.Y. and Y.W.; writing - review and editing, X.W. and Y.W.; visualization, X.W. and Y.W.; supervision, X.W. and Y.W.; project administration, X.W. and Y.W.; funding acquisition, Y.W. All authors have read and agreed to the published version of the manuscript.

Funding: This study was funded by the National Key R\&D Program of China (2017YFC1404300, X.W.) and the National Science Foundation of China (41976082 and 41676144, Y.W.).

Institutional Review Board Statement: Not applicable.

Informed Consent Statement: Not applicable.

Data Availability Statement: Data sharing not applicable.

Acknowledgments: We thank three anonymous reviewers for their constructive comments.

Conflicts of Interest: The authors declare no competing financial interests. 


\section{References}

1. Field, C.B.; Behrenfeld, M.J.; Randerson, J.T.; Falkowski, P. Primary production of the biosphere: Integrating terrestrial and oceanic components. Science 1998, 281, 237-240. [CrossRef]

2. Falkowski, P.G.; Barber, R.T.; Smetacek, V. Biogeochemical controls and feedbacks on ocean primary production. Science 1998, 281, 200-206. [CrossRef] [PubMed]

3. Huisman, J.; Jonker, R.R.; Zonneveld, C.; Weissing, F.J. Competition for light between phytoplankton species: Experimental tests of mechanistic theory. Ecology 1999, 80, 211-222. [CrossRef]

4. Sommer, U. Phytoplankton succession in microcosm experiments under simultaneous grazing pressure and resource limitation. Limnol. Oceanogr. 1988, 33, 1037-1054. [CrossRef]

5. Cermeño, P.; Lee, J.B.; Wyman, K.; Schofield, O.; Falkowski, P.G. Competitive dynamics in two species of marine phytoplankton under non-equilibrium conditions. Mar. Ecol. Prog. Ser. 2011, 429, 19-28. [CrossRef]

6. Litchman, E.; Klausmeier, C.A.; Schofield, O.M.; Falkowski, P.G. The role of functional traits and trade-offs in structuring phytoplankton communities: Scaling from cellular to ecosystem level. Ecol. Lett. 2007, 10, 1170-1181. [CrossRef]

7. Marañón, E. Cell size as a key determinant of phytoplankton metabolism and community structure. Ann. Rev. Mar. Sci. 2015, 7, 242-264. [CrossRef]

8. Legrand, C.; Rengefors, K.; Fistarol, G.O.; Granéli, E. Allelopathy in phytoplankton—Biochemical, ecological and evolutionary aspects. Phycologia 2003, 42, 406-419. [CrossRef]

9. Granéli, E.; Hansen, P.J. Allelopathy harmful algae: A mechanism to compete for resources? In Ecology of Harmful Algae, Ecological Studies; Granéli, E., Turner, J.T., Eds.; Springer: Berlin/Heidelberg, Germany, 2006; pp. 189-201.

10. Felpeto, A.B.; Roy, S.; Vasconcelos, V.M. Allelopathy prevents competitive exclusion and promotes phytoplankton biodiversity. Oikos 2018, 127, 85-98. [CrossRef]

11. Fistarol, G.O.; Legrand, C.; Granéli, E. Allelopathic effect of Prymnesium parvumon a natural plankton community. Mar. Ecol. Prog. Ser. 2003, 255, 115-125. [CrossRef]

12. Kubanek, J.; Hicks, M.K.; Naar, J.; Villareal, T.A. Does the red tide dinoflagellate Karenia brevis use allelopathy to outcompete other phytoplankton? Limnol. Oceanogr. 2005, 50, 883-895. [CrossRef]

13. Yamasaki, Y.; Nagasoe, S.; Matsubara, T.; Shikata, T.; Shimasaki, Y.; Oshima, Y.; Honjo, T. Allelopathic interactions between the bacillariophyte Skeletonema costatum and the raphidophyte Heterosigma akashiwo. Mar. Ecol. Prog. Ser. 2007, 339, 83-92. [CrossRef]

14. Prince, E.K.; Myers, T.L.; Kubanek, J. Effects of harmful algal blooms on competitors: Allelopathic mechanisms of the red tide dinoflagellate Karenia brevis. Limnol. Oceanogr. 2008, 53, 531-541. [CrossRef]

15. Tang, Y.Z.; Gobler, C.J. Allelopathic effects of Cochlodinium polykrikoides isolates and blooms from the estuaries of Long Island, New York USA on cooccurring phytoplankton. Mar. Ecol. Prog. Ser. 2010, 406, 19-31. [CrossRef]

16. Granéli, E.; Weberg, M.; Salomon, P.S. Harmful algal blooms of allelopathic microalgal species: The role of eutrophication. Harmful Algae 2008, 8, 94-102. [CrossRef]

17. Jonsson, P.R.; Pavia, H.; Toth, G. Formation of harmful algal blooms cannot be explained by allelopathic interactions. Proc. Natl. Acad. Sci. USA 2009, 106, 11177-11182. [CrossRef] [PubMed]

18. Tillmann, U.; John, U.; Cembella, A. On the allelochemical potency of the marine dinoflagellate Alexandrium ostenfeldii against heterotrophic and autotrophic protists. J. Plankton Res. 2007, 29, 527-543. [CrossRef]

19. Suikkanen, S.; Hakanen, P.; Spilling, K.; Kremp, A. Allelopathic effects of Baltic Sea spring bloom dinoflagellates on co-occurring phytoplankton. Mar. Ecol. Prog. Ser. 2011, 439, 45-55. [CrossRef]

20. Uchida, T.; Toda, S.; Matsuyama, Y.; Yamaguchi, M.; Kotani, Y.; Honjo, T. Interactions between the red tide dinoflagellates Heterocapsa circularisquama and Gymnodinium mikimotoi in laboratory culture. J. Exp. Mar. Biol. Ecol. 1999, 241, 285-299. [CrossRef]

21. Tameishi, M.; Yamasaki, Y.; Nagasoe, S.; Shimasaki, Y.; Oshima, Y.; Honjo, T. Allelopathic effects of the dinophyte Prorocentrum minimum on the growth of the bacillariophyte Skeletonema costatum. Harmful Algae 2009, 8, 421-429. [CrossRef]

22. Poulson, K.L.; Sieg, R.D.; Prince, E.K.; Kubanek, J. Allelopathic compounds of a red tide dinoflagellate have species-specific and context-dependent impacts on phytoplankton. Mar. Ecol. Prog. Ser. 2010, 416, 69-78. [CrossRef]

23. Uchida, T.; Yamaguchi, M.; Matsuyama, Y.; Honjo, T. The red-tide dinoflagellate Heterocapsa sp. kills Gyrodinium instriatum by cell contact. Mar. Ecol. Prog. Ser. 1995, 118, 301-303. [CrossRef]

24. Corcoran, A.A.; Seger, M.; Niu, R.; Nirmalakhandan, N.; Lammers, P.J.; Holguin, F.O.; Boeing, W.J. Evidence for induced allelopathy in an isolate of Coelastrella following co-culture with Chlorella sorokiniana. Algal. Res. 2019, 41, 101535. [CrossRef]

25. Paul, C.; Barofsky, A.; Vidoudez, C.; Pohnert, G. Diatom exudates influence metabolism and cell growth of co-cultured diatom species. Mar. Ecol. Prog. Ser. 2009, 389, 61-70. [CrossRef]

26. Smith, W.O., Jr.; Codispoti, L.A.; Nelson, D.M.; Manley, T.; Buskey, E.J.; Niebauer, H.J.; Cota, G.F. Importance of Phaeocystis blooms in the high-latitude ocean carbon cycle. Nature 1991, 352, 514-516. [CrossRef]

27. Lancelot, C.; Keller, M.D.; Rousseau, V.; Smith, W.O.; Mathot, S. Autecology of the marine haptophyte Phaeocystiss pp. In Physiological Ecology of Harmful Algal Blooms; NATO ASI Series; Anderson, D.M., Cembella, A.D., Hallegraef, G.M., Eds.; Springer: Berlin, Germany, 1998; Volume 41, pp. 209-224.

28. Schoemann, V.; Becquevort, S.; Stefels, J.; Rousseau, W.; Lancelot, C. Phaeocystis blooms in the global ocean and their controlling mechanisms: A review. J. Sea Res. 2005, 53, 43-66. [CrossRef] 
29. Rousseau, V.; Chrétiennot-Dinet, M.J.; Jacobsen, A.; Verity, P.; Whipple, S. The life cycle of Phaeocystis: State of knowledge and presumptive role in ecology. Biogeochemistry 2007, 83, 29-47. [CrossRef]

30. Qi, Y.Z.; Chen, J.F.; Wang, Z.H.; Xu, N.; Wang, Y.; Shen, P.P.; Lu, S.H.; Hodgkiss, I.J. Some observations on harmful algal bloom (HAB) events along the coast of Guangdong, southern China in 1998. Hydrobiologia 2004, 51, 209-214. [CrossRef]

31. Peperzak, L.; Colijn, F.; Gieskes, W.W.C.; Peeters, J.H.C. Development of the diatom-Phaeocystis spring bloom in the Dutch coastal zone of the North Sea: The silicon depletion versus the daily irradiance threshold hypothesis. J. Plankton Res. 1998, 20, 517-537. [CrossRef]

32. Rousseau, V.; Leynaert, A.; Daoud, N.; Lancelot, C. Diatom succession, silicification and silicic acid availability in Belgian coastal waters (southern North Sea). Mar. Ecol. Prog. Ser. 2002, 236, 61-73. [CrossRef]

33. Breton, E.; Rousseau, V.; Parent, J.Y.; Ozer, J.; Lancelot, C. Hydroclimatic modulation of diatom/Phaeocystis blooms in nutrientenriched Belgian coastal waters (North Sea). Limnol. Oceanogr. 2006, 51, 1401-1409. [CrossRef]

34. Gypens, N.; Lacroix, G.; Lancelot, C. Causes of variability in diatom and Phaeocystis blooms in Belgian coastal waters between 1989 and 2003: A model study. J. Sea Res. 2007, 57, 19-35. [CrossRef]

35. He, C.; Song, S.; Li, C. The spatial-temporal distribution of Phaeocytis globosa colonies and related affecting factors in Guangxi Beibu Gulf (in Chinese, with English abstract). Oceanol. Limnol. Sin. 2019, 50, 630-643.

36. Guillard, R.R.L.; Ryther, J.H. Studies of marine planktonic diatoms: I. Cyclotella nana Hustedt, and Detonula confervacea (cleve) Gran. Can. J. Microbiol. 1962, 8, 229-239. [CrossRef] [PubMed]

37. Tang, K.T. Grazing and colony size development in Phaeocystis globosa (Prymnesiophyceae): The role of a chemical signal. J. Plankton Res. 2003, 25, 831-842. [CrossRef]

38. Wang, X.; Tang, K.W.; Wang, Y.; Smith, J.R.W.O. Temperature effects on growth, colony development and carbon partitioning in three Phaeocystis species. Aquat. Biol. 2010, 9, 239-249. [CrossRef]

39. Sun, J.; Liu, D.Y. Geometric models for calculating cell biovolume and surface area for phytoplankton. J. Plankton Res. 2003, 25, 1331-1346. [CrossRef]

40. Menden-Deuer, S.; Lessard, E.J. Carbon to volume relationships for dinoflagellates, diatoms, and other protist plankton. Limnol. Oceanogr. 2000, 45, 569-579. [CrossRef]

41. Grasshoff, K.; Ehrhardt, M.; Kremling, K. Methods of Seawater Analysis; John Wiley \& Sons: Weinheim, Germany, 1999.

42. Wang, X.; Wang, Y.; Ou, L.; He, X.; Chen, D. Allocation costs associated with induced defense in Phaeocystis globosa (Prymnesiophyceae): The effects of nutrient availability. Sci. Rep. 2015, 5, 10850. [CrossRef]

43. Pedersen, M.F.; Hansen, P.J. Effects of high $\mathrm{pH}$ on the growth and survival of six marine heterotrophic protists. Mar. Ecol. Prog. Ser. 2003, 260, 33-41. [CrossRef]

44. Lundholm, N.; Hansen, P.J.; Kotaki, Y. Lack of allelopathic effects of the domoic acid-producing marine diatom Pseudo-nitzschia multiseries. Mar. Ecol. Prog. Ser. 2005, 288, 21-33. [CrossRef]

45. Riisgaard, K.; Nielsen, T.G.; Hansen, P.J. Impact of elevated pH on succession in the Arctic spring bloom. Mar. Ecol. Prog. Ser. 2015, 530, 63-75. [CrossRef]

46. Yamasaki, Y.; Zou, Y.; Go, J.; Shikata, T.; Matsuyama, Y.; Nagai, K.; Shimasaki, Y.; Yamaguchi, K.; Oshima, Y.; Oda, T.; et al. Cell contact-dependent lethal effect of the dinoflagellate Heterocapsa circularisquama on phytoplankton-phytoplankton interactions. J. Sea Res. 2011, 65, 76-83. [CrossRef]

47. Hulot, F.D.; Huisman, J. Allelopathic interactions between phytoplankton species: The roles of heterotrophic bacteria and mixing intensity. Limnol. Oceanogr. 2004, 49, 1424-1434. [CrossRef]

48. Suikkanen, S.; Fistarol, G.O.; Granéli, E. Allelopathic effects of the Baltic cyanobacteria Nodularia spumdigena, Aphanizomenon flos-aquae and Anabaena lemmermannii on algal monocultures. J. Exp. Mar. Biol. Ecol. 2004, 308, 85-101. [CrossRef]

49. Fistarol, G.O.; Legrand, C.; Granéli, E. Allelopathic effect on a nutrient-limited phytoplankton species. Aquat. Microb. Ecol. 2005, 41, 153-161. [CrossRef]

50. Myers, T.L.; Prince, E.K.; Naar, J.; Kubanek, J. Loss of waterborne brevetoxins from exposure to phytoplankton competitors. Harmful Algae 2008, 7, 762-771. [CrossRef]

51. Davidson, A.T.; Marchant, H.J. Binding of manganese by Antarctic Phaeocystis pouchetii and the role of bacteria in its release. Mar. Biol. 1987, 95, 481-487. [CrossRef]

52. Lancelot, C. The mucilage phenomenon in the continental coastal waters of the North-Sea. Sci. Total Environ. 1995, 165, 83-102. [CrossRef]

53. Poulson-Ellestad, K.L.; Jones, C.M.; Roy, J.; Viant, M.R.; Fernandez, F.M.; Kubanek, J.; Nunn, B.L. Metabolomics and proteomics reveal impacts of chemically mediated competition on marine plankton. Proc. Natl. Acad. Sci. USA 2014, 111, 9009-9014. [CrossRef]

54. Lewis, W.M., Jr. Evolutionary interpretations of allelochemical interactions in phytoplankton algae. Am. Nat. 1986, 127, 184-194. [CrossRef]

55. Hamm, C.E. Architecture, ecology and biogeochemistry of Phaeocystis colonies. J. Sea Res. 2000, 43, 307-315. [CrossRef]

56. Nejstgaard, J.C.; Tang, K.W.; Steinke, M.; Dutz, J.; Koski, M.; Antajan, E.; Long, J.D. Zooplankton grazing on Phaeocystis: A quantitative review and future challenges. Biogeochemistry 2007, 83, 147-172. [CrossRef]

57. Hamm, C.E.; Simson, D.A.; Merkel, R.; Smetacek, V. Colonies of Phaeocystis globosa are protected by a thin but tough skin. Mar. Ecol. Prog. Ser. 1999, 187, 101-111. [CrossRef] 
58. Irigoien, X.; Flynn, K.J.; Harris, R.P. Phytoplankton blooms: A ‘loophole' in microzooplankton grazing impact? J. Plankton Res. 2005, 27, 313-321. [CrossRef]

59. Smith, W.O., Jr.; Liu, X.; Tang, K.W.; DeLizo, L.M.; Doan, N.H.; Nguyen, N.L.; Wang, X. Giantism and its role in the harmful algal bloom species Phaeocystis globosa. Deep Sea Res. Part II Top. Stud. Oceanogr. 2014, 101, 95-106. [CrossRef]

60. Wang, X.; Wang, Y.; Ou, L. The roles of light-dark cycles in the growth of Phaeocystis globosa from the South China Sea: The cost of colony enlargement. J. Sea. Res. 2014, 85, 518-523. [CrossRef]

61. Jakobsen, H.H.; Tang, K.T. Effects of protozoan grazing on colony formation in Phaeocystis globosa (Prymnesiophyceae) and the potential costs and benefits. Aquat. Microb. Ecol. 2002, 27, 261-271. [CrossRef] 